\title{
SEJ ARAH DAN DINAMIKA SOSIAL FIQIH REFORMIS DAN FIQIH TRADISIONALIS DI INDONESIA
}

\author{
Abd. Salam*
}

\begin{abstract}
A bstract: This paper is aimed at describing the history and the social dynamics of the reformist and traditionalist figh in Indonesia. It first tries to show that since the $13^{\text {th }}$ century Islam in Indonesia has largely been Sufi-oriented. It was only fairly recently that Islam in this country came into contact with figh especially after the return of Indonesian students from the Middle East toward the end of the $19^{\text {th }}$ century. The puritan and reformist movements that prevailed in the Middle East at the time especially those under the patronage of M uhammad Abdul Wahhab and J amaluddin al-Afghani inspired Muslims of this country to launch a similar reform in Indonesia. This reform movement received a somewhat strong opposition from the traditionalists since the beginning of the $20^{\text {th }}$ century, hence the tension between the two currents of thought. This paper pays particular attention to this dynamic tension in the context of the contemporary historical and legal development in Indonesia.
\end{abstract}

Keywords: reformist, traditionalist, fiqh, dynamic tension

\section{Pendahuluan}

Pada permulaan abad ke-20 Masehi, lembar sejarah sosial umat Islam Indonesia diwarnai oleh suasana ketegangan antara kaum reformis dan kaum tradisionalis ${ }^{1}$ menyangkut isu-isu keagamaan yang umumnya mengenai persoalan-persoalan fiqih dan/atau uskl|sal-fiqh. Dengan menengok sedikit ke belakang, ketegangan tersebut pada dasarnya dapat dilihat sebagai perkembangan lebih lanjut dari perubahan orientasi keilmuan Islam yang terjadi pada abad ke19 Masehi dari kecenderungan yang kuat pada tasawuf menjadi fiqh oriented. Kecenderungan pada tasawuf terjadi karena Islam yang masuk ke Indonesia pada abad ke-13 Masehi adalah Islam dalam bentuk yang sudah dikembangkan di Persia dan kemudian di anak Benua India. Perubahannya menjadi figh oriented terjadi sesudah Indonesia menjalin kontak ilmiah langsung dengan Timur Tengah yang mulai berjalan intens pada akhir abad ke-19 Masehi.

Mengacu pada hasil studi yang dilakukan oleh A.H. J ohns, dapat disimpulkan bahwa kontak ilmiah itu sudah terjadi dalam kadar dan kualitas yang terbatas semenjak abad ke-16 Masehi. Studi J ohns, sebagaimana disitir Zamakhsyari Dhofier, mengungkapkan bahwa para ulama Indonesia pada abad ke-16 dan 17 Masehi banyak mengadakan hubungan surat-menyurat

\footnotetext{
${ }^{*}$ Fakultas Syariah IAIN Sunan Ampel Surabaya

${ }^{1}$ Terdapat ragam pemakaian nomenklatur dalam menyebut kelompok-kelompok Islam di Indonesia. Harry J. Benda menyebutnya dengan Reformis dan Ortodoks. Baca: Hary J. Benda, Bulan Sabit dan M atahari Terbit, penerjemah: Daniel Dakhidae (J akarta: Dunia Pustaka J aya, 1980), 74-75. Menurut Boland, kelompok Reformis disebut juga dengan Modernis. Lawannya disebut Ortodoks, Konservatif, Tradisionalis. Baca: B.J. B oland, The Struggle of Islam in Modern Indonesia (The Hague: Martinus N ijhoff, 1982), 211-224. Abu Bakar Atjeh memakai sebutan "Salaf" untuk kelompok yang berusaha keras mengembalikan ajaran Islam kepada Qur'an dan Sunnah, mengikis habis bid'ah dan khurafat, takhayyul dan klenik, membuka pintu ijtihad, dan menolak taqlid. Untuk lawannya, yaitu kelompok yang tidak menyetujui pandangan kritis kelompok salaf ini, digunakan sebutan "Modernis". Untuk pemakaian nomenklatur Salaf dan Modernis, Steenbrink mengikuti Aboebakar Atjeh. Baca: Lothrop Stoddard, Dunia Baru Islam (J akarta, 1966), 318; Steenbrink, Pesantren, Sekolah: Pendidikan Islan dalam Kurun Modern, cetakan 2 (J akarta: LP3ES, 1994), 33-34.
} 
(korespondensi) dengan ulama semenanjung A rabia. Ulama Indonesia juga sering mengundang ulama-ulama India dan Timur Tengah. Mereka yang diundang itu datang ke Indonesia dengan membawa buku-buku tafsir, fiqih, dan lain-lain. Di samping itu, para ulama Aceh banyak yang pergi haji dan kemudian tinggal beberapa waktu lamanya untuk memperdalam pengetahuan agama Islam kepada ulama di negeri $\mathrm{H}$ ijaz dan Yaman. ${ }^{2}$ Sedangkan kontak yang intens baru terjadi pada abad ke-19 Masehi, terutama sesudah dibukanya terusan Suez pada tahun 1869 yang membawa dampak positif pada kelancaran arus transportasi laut sehingga pengiriman santri (pelajar) untuk memperdalam pengetahuan agama Islam di Timur Tengah bisa berlangsung lebih teratur. Kelancaraan arus transportasi laut itu juga berdampak positif pada perjalanan haji, sehingga terbuka peluang bagi lebih banyak elite muslim terpelajar Indonesia, yang kedatangannya ke Mekah hanya bermaksud melakukan rihlah muqaddasah (perjalanan suci) itu saja, untuk sekaligus bersentuhan langsung dengan aneka pemikiran dan realitas perkembangan Islam di Timur Tengah.

\section{Munculnya Reformis dan Tradionalis}

Pada akhir abad ke-19 itu di Timur Tengah sedang merebak gerakan purifikasi (pemurnian) dan reformasi (pembaruan) Islam, seperti gerakan Wahabi ${ }^{3}$ di semenanjung Arabia yang kemunculannya pada abad ke-18 Masehi dimotori oleh Muhæ̧mmad bin 'A bd al-Wahhab (11151206/1703-1792), dan ide Pan-Islamisme ${ }^{4}$ yang dicetuskan oleh J amaluddin al-Afghani (18381897) pada abad ke-19 Masehi dan dilanjutkan oleh muridnya: Muhł̧mmad 'Abduh (12651323/1849-1905) di Mesir. ${ }^{5}$ Kontak ilmiah yang intens dengan Timur Tengah sepanjang periode tersebut telah pula membawa realitas perkembangan Islam di sana hadir lebih dekat dan membentuk cita tersendiri dalam alam kesadaran keagamaan elite muslim Indonesia.

Dengan kata lain, angin pembaruan Islam yang berhembus kencang di Timur Tengah turut mengilhami beberapa elite muslim Indonesia untuk melakukan reformasi Islam di tanah air. Diperkuat pula dengan bahan-bahan bacaan dari Mesir, termasuk majalah al-Manaryang

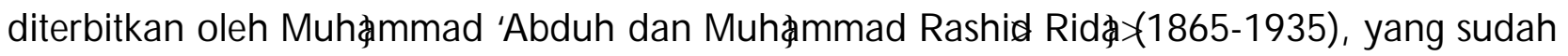
masuk dan beredar secara terbatas di Indonesia. ${ }^{6} \mathrm{G}$ erakan pembaruan Islam yang dimotori 'A bduh

${ }^{2}$ Ridwan, Paradigma Politik NU: Relasi Sunni-NU dalam Pemikiran Politik (Purwokerto: STAIN Purwokerto Press, 2004), 171.

${ }^{3}$ Wahabi tidak berlatarbelakang politik, tetapi murni keagamaan. Gerakan ini bergulat dengan persoalan keagamaan internal umat Islam, terutama faham tauhid kaum muslimin yang telah dipengaruhi ajaran tarekat sehingga menghargai para imam tarekat sebagai wali dan memuliakan makam mereka, dan tradisi keagamaan lainnya yang dianggap menyimpang dari syariat Islam. Gerakan ini sangat radikal dan tidak kenal kompromi terhadap ajaran-ajaran yang tidak Islami, dan takhayyul yang dikaitkan dengan ajaran tarekat tersebut. Baca: M. Ali Haidar, NU dan Islam di Indonesia: Pendekatan Fikih dalam Politik (J akarta: PT Gramedia Pustaka Utama, 1994), 118; Achmad J aenuri, Ideologi Kaum Reformis: Melacak Pandangan Keagamaan Muhammadiyah Periode Awal (Surabaya: LPAM, 2002), 15.

4Pan Islamisme (dalam bahasa A rab disebut al-J ami'ah al-Islamiyah) ialah paham yang bertujuan untuk menyatukan Islam sedunia. Munculnya ide Pan Islamisme erat kaitannya dengan kondisi abad ke-19 yang merupakan abad kemunduran dunia Islam, sementara dunia Barat mengalami kemajuan dan menguasai (menjajah) negeri-negeri Islam. Kondisi ini membangkitkan obsesi yang kuat untuk menggalang dan mewujudkan upaya penyatuan dunia Islam. Baca: Dewan Redaksi Ensiklopedi Islam, "Pan Islamisme”, Ensiklopedi Islam, Vol. 3 (J akarta: PT Ichtiar Baru Van Hoeve, 1993), Vol. 4, 79-80.

${ }^{5}$ Ridwan, Paradigma Politik NU, 177.

${ }^{6}$ lbid., 
menekankan pada pentingnya pengembangan ijtihad oleh kaum muslimin. Sebab, menurut 'Abduh, salah satu faktor yang menyebabkan kaum muslimin mengalami kemunduran dan tertinggal oleh Barat ialah karena ijtihad-yang terbukti telah mengantarkan para pendahulu mereka menuju puncak pencapaian yang mengagumkan-dicampakkan dan tidak lagi dikembangkan oleh mereka. ${ }^{7}$

Pada abad ke-19 M. kaum muslimin memang mengalami kemunduran di segala bidang. Bukan saja di lapangan ilmu pengetahuan dan teknologi mereka tertinggal jauh dari bangsa Barat, melainkan secara politis kaum muslimin sangat lemah sehingga negeri-negeri mereka dikuasai dan dijajah oleh Barat. Spirit pembaruan yang dihembuskan 'Abduh dan para penyokongnya berusaha menyadarkan umat Islam untuk tidak membiarkan diri mereka terus dibelenggu oleh rasa bangga terhadap masa lalu. J ika mereka begitu menjunjung masa lalu sebagai puncak kejayaan dan kemajuan Islam yang mustahil disejajari-apalagi diunggulimaka sesuatu yang esensial dan amat berharga menjadi sirna dari kehidupan kaum muslimin, yakni ruh dan tradisi ijtihad.

Pemikiran-pemikiran semacam itu dan berbagai informasi mengenai manifestasinya di berbagai kawasan lain, termasuk kemajuan yang bisa disaksikan dari realitas kehidupan modern bangsa Barat (dalam hal ini penjajah Belanda di tanah air), cukup kuat menstimulasi elite muslim Indonesia untuk segera melakukan reformasi Islam. Pada awal abad ke-20 M., sejarah mencatat bahwa gerakan reformasi Islam mulai bergulir di Indonesia, tidak hanya pada kawasan rekonstruksi doktrinal, melainkan juga pada wilayah sosial keumatan. Kaum muslimin Indonesia dalam periode tersebut menyaksikan lahirnya sejumlah gerakan (organisasi) Islam. Mulai dari J ami'at Khair pada tahun 1903, ${ }^{8}$ kemudian diikuti secara berturut-turut oleh Sarekat Dagang Islam (SDI) pada tahun 1905, yang pada tanggal 10 September 1912 berubah nama menjadi Sarekat Islam (SI), ${ }^{9}$

\footnotetext{
${ }^{7} \mathrm{H}$ arun Nasution, Pembaharuan dalam Islam: Sejarah Pemikiran dan Gerakan (J akarta: B ulan Bintang, 1975), 64. 8f ami'at Khair adalah perkumpulan masyarakat Islam Indonesia yang didirikan di I akarta oleh Sayid Muhammad al-Faqisibn Abdurrahman al-Manshusdan kawan-kawannya. Sebenarnya mereka telah mendirikan al-J am'iyah alKhairiyah pada tahun 1901, namun permohonan izin berdirinya kepada pemerintah baru diajukan pada tahun 1903. Izin resmi terbit pada tahun 1905 dengan syarat tidak boleh mendirikan cabang di luar J akarta. Cabang J ami'at Khair didirikan di Surabaya pada tahun 1909 atas rintisan M uhammad al-Muhdłr dan kawan-kawannya, yang dalam perkembangannya kemudian menjadi Yayasan al-Khairiyah atau Mabarrat al-Khairiyah Surabaya. Di Indonesia, J ami'at Khair merupakan organisasi Islam pertama yang hadir dalam bentuk modern yang ditandai dengan adanya anggaran dasar, daftar anggota, dan penyelenggaraan rapat-rapat berkala. Organisasi ini juga mendirikan sekolah dengan menggunakan kurikulum, kelas, bangku, dan papan tulis. Guru-gurunya sebagian didatangkan dari luar daerah dan luar negeri, di antaranya Ahmad Surkati dari Sudan, Muhammad T aaib dari Maroko, dan Muhammad 'Abdul Hamid dari Mekah. A hmad Surkati merupakan guru yang paling menonjol di J ami'at Khair karena ide-ide pembaruannya yang menyebabkan terjadinya perpecahan di tubuh organisasi ini antara keturunan Arab golongan Sayid dan bukan Sayid. A hmad Surkati dan kawan-kawannya yang bukan Sayid kemudian ke luar dari J ami'at Khair dan mendirikan al-Irsyad pada tahun 1913. Baca: Dewan Redaksi,"'J ami'at Khair", Ensiklopedi Islam, Vol. 2, 302-303, dan Mas'an Hamid, "Tradisi Pembacaan Simtal-Durar dalam Masyarakat Keturunan Arab di Kawasan Ampel Surabaya: Kajian Tentang Bentuk, Isi, dan Fungsi Sastra'“(Disertasi Doktor pada IAIN Sunan Ampel, Surabaya, 2008), 135

${ }^{9} \mathrm{SDI}$ didirikan oleh Haji Samanhudi (seorang saudagar batik kaya di Solo, J awa Tengah). Beberapa pendapat mencoba menjelaskan bahwa SDI didirikan, pertama, untuk menghadapi persaingan dengan orang Cina dan sikap superioritas mereka terhadap orang Indonesia. Dengan dukungan ordonansi Hindia Belanda yang memberi mereka ruang gerak yang lebih besar, pedagang Cina mendirikan Sianghwee (Kamar Dagang) di kota-kota besar sehingga mereka dapat membeli bahan-bahan langsung dari importir. Sebaliknya, dalam kasus usaha batik, misalnya, para pengusaha J awa harus membeli bahan dari pedagang Timur Asing, khususnya Cina. Akibatnya, batik produksi
} 
Muhammadiyah pada tahun $1912,{ }^{10}$ al-Irsyad pada tahun $1914,{ }^{11}$ dan Persatuan Islam (PERSIS) pada tahun $1923 .{ }^{12}$

Di luar arus utama reformasi ini, sejumlah elite terpelajar muslim dari lingkungan pesantren-yang juga sempat mengenyam kontak ilmiah langsung dengan Timur Tengahtidak dapatmenerima bulat-bulat gagasan reformasi itu. Mereka tidak sependapat dengan agenda purifikasi Islam yang dicanangkan oleh para reformis itu karena orientasinya pada gerakan perombakan tradisi secara total. Bagi mereka, purifikasi Islam itu tidak harus mengejawantah dalam perombakan tradisi secara frontal dan radikal karena hal itu akan mengguncang masyarakat. Bertolak dari pandangan ini mereka lalu mengambil posisi untuk menempuh cara-cara yang lebih luwes dalam menyelaraskan tradisi lokal dengan Islam. ${ }^{13}$ Selanjutnya mereka melakukan konsolidasi dengan mendirikan organisasi yang diberi nama Nahdlatul Ulama (NU) pada tanggal 31 J anuari 1926 (16 Rajab 1344 H.).

Kajian ilmiah tentang gerakan-gerakan Islam yang muncul di berbagai negeri muslim, ada yang memolakan orientasi ideologisnya menjadi tiga: tradisionalis-konservatif, reformis-

perusahaan J awa lebih mahal daripada batik produksi perusahaan Timur Asing, sehingga pasar batik dikuasai orang-orang Cina. Kedua, untuk menghadapi tekanan dari kalangan bangsawan (Mangkunegaran) yang dirasakan masyarakat Indonesia di Solo ketika itu. Ketiga, untuk membuat front perlawanan menghadapi semua penghinaan terhadap rakyat bumiputera. Keempat, sebagai perlawanan terhadap kecurangan dan penindasan yang dilakukan oleh pegawai Bumiputera dan Eropa terhadap rakyat. Perubahan nama menjadi SI dimaksudkan untuk memperluas keanggotaannya. Perubahan nama ini menunjukkan juga terjadinya perubahan orientasi dari komersial ke politik. Baca: Dewan Redaksi, "Sarekat Islam", Ibid., Vol. 4, 253. Perkembangan SI sempat disambut dengan antusias oleh sejumlah santri yang menuntut ilmu di Mekah, antara lain Abdul Wahab Hasbullah, Muhammad Dahlan, Asnawi, dan Abbas. Mereka kemudian mendirikan cabang SI di Mekah. Namun, karena perang dunia segera pecah, mereka pulang ke Indonesia sebelum sempat mengembangkan organisasi tersebut. Lihat: Ali, NU dan Islam di Indonesia, 41.

${ }^{10}$ M uhammadiyah didirikan oleh Kiai Haji A hmad Dahlan pada 18 Nopember 1912 (8 Zulhijjah 1330) di Yogyakarta. Menurut kalangan Muhammadiyah, faktor-faktor yang menjadi alasan Kiai Haji Ahmad Dahlan mendirikan organisasi ini adalah: Pertama, ia melihat umat Islam tidak memegang teguh al-Q ur'an dan Sunnah dalam beramal sehingga takhayyul dan shirk merajalela, dan akhlak masyarakat runtuh. Amalan-amalan mereka merupakan campuran antara yang benar dan yang salah. Kedua, lembaga-lembaga pendidikan agama yang ada pada waktu itu dipandang tidak efisien. Pesantren, yang menjadi lembaga pendidikan kalangan bawah, dinilai tidak sesuai lagi dengan perkembangan kebutuhan masyarakat. Ketiga, di tengah kemiskinan yang menimpa umat, yang sebagian besarnya adalah petani dan buruh, orang kaya hanya mementingkan dirinya sendiri, dan banyak ulama lupa mengingatkan mereka mengenai kewajiban zakat. Keempat, gencarnya aktifitas misi Katolik dan Protestan, dan bahkan sekolahsekolah misi mendapat subsidi dari pemerintah Hindia B elanda. Kelima, kebanyakan umat Islam hidup dalam fanatisme yang sempit, bertaklid buta, serta berfikir secara dogmatis. Kehidupan umat Islam masih diwarnai konservatisme, formalisme, dan tradisionalisme. Baca: Dewan Redaksi, “Muhammadiyah", Ensiklopedi Islam, Vol. $3,275$.

${ }^{11}$ Al-Irsyad didirikan oleh sejumlah ulama dan pedagang Arab di J akarta, di antaranya Ahmad Surkati, Umar Manggus, Saleh bin Ubaid, Sayid bin Salim Masyhabi, Salim bin Umar Balfas, Abdullah Harharah, dan Umar bin Saleh bin Nahdi. Al-Irsyad bergerak dalam bidang pendidikan dan sosial keagamaan. Gagasan pembaruan yang diusung organisasi ini dalam bidang pendidikan banyak diilhami oleh sistem pendidikan yang dibawa oleh Muhł̧mmad 'A bduh dan, muridnya, Muhammad Rashid Ridł>B aca Ibid., "Al-Irsyad", Ensiklopedi Islam, Vol. 2, 245.

${ }^{12}$ PERSIS didirikan di B andung pada tanggal 17 September 1923 oleh K.H. Zamzam yang berasal dari Palembang. Kelahiran PERSIS diawali dari kegiatan grup diskusi pengajian agama yang diselenggarakan pada awal tahun duapuluhan oleh sejumlah saudagar asal Palembang yang tinggal Bandung. Organisasi ini berusaha keras untuk mengembalikan kaum muslimin kepada pimpinan al-Qur'an dan $\mathrm{H}$ \{adith, menghidupkan jihad dan ijtihad, membasmi bid'ah, khurafat, takhayul, taqlid, dan shirk, memperluas tabligh dan dakwah Islam kepada segenap masyarakat, mendirikan pesantren dan sekolah untuk mendidik kader Islam. Baca: Ibid. "Persatuan Islam”, Ensiklopedi Islam, Vol. 4, 95. Baca juga: M. Ali Haidar, NU dan Islam, 49.

${ }^{13} \mathrm{~A}$. Gaffar Karim, Metamorfosis NU dan Politisasi Islam Indonesia (Yogyakarta: LKiS, 1995), 47-48. 
modernis, dan radikal-puritan. Kaum tradisionalis-konservatif berasal dari, khususnya, kalangan ulama dan pengikut tarekat, serta umumnya kalangan penduduk pedesaan dan kelas bawah. Mereka menolak kecenderungan westernisasi (pembaruan) atas nama Islam seperti yang dipahami dan dipraktikkan di kawasan-kawasan tertentu. Kaum reformis-modernis memandang Islam sebagai shariłat yang relevan untuk semua lapangan kehidupan, baik pribadi maupun publik, tetapi mereka menekankan fleksibilitas dan cenderung menafsirkan Islam dengan menggunakan ide dan metode yang berasal dari Barat. Pandangan-pandangan dan praktik-praktik tradisional, menurut mereka, harus direformasi berdasarkan sumber-sumber asli yang otoritatif, yakni alQur'an dan Sunnah, dalam konteks situasi dan kebutuhan kontemporer. Kaum radikal-puritan juga menafsirkan Islam berdasarkan sumber-sumber asli yang otoritatif sesuai dengan kebutuhan kontemporer, tetapi mereka sangat keberatan dengan tendensi modernis untuk mem-Barat-kan Islam. Mereka juga memandang sharisah itu fleksibel dan bisa berkembang untuk memenuhi kebutuhan yang terus berubah, tetapi penafsiran dan pengembangan itu harus dilakukan melalui cara Islam yang murni. Mereka juga mengritik gagasan-gagasan dan praktik-praktik kaum tradisional. ${ }^{14}$

Hasil identifikasi para ilmuwan terhadap orientasi ideologis gerakan-gerakan Islam tertentu di Indonesia pada awal abad ke-20 memosisikan SI, Muhammadiyah, dan al-Irsyad sebagai modernis. sedangkan NU sebagai tradisionalis. ${ }^{15}$ Beberapa sarjana juga memasukkan PERSIS sebagai modernis, tetapi beberapa yang lain cenderung menyebutnya sebagai radikalis. ${ }^{16}$ Identifikasi ini memperjelas posisi NU sebagai gerakan yang berada di luar mainstream gerakan reformasi Islam yang sedang bergulir ketika itu. Bahkan NU bukan hanya di luar, melainkan justru "memasang badan" untuk membendung arus reformasi tersebut karena dipandang akan mencerabut Islam dari akar tradisinya yang telah mapan di Indonesia. Sikap NU yang secara ideologis ekstrim membela pandangan keagamaan kelompok tradisionalis ini, menurut J aenuri,

\footnotetext{
${ }^{14} \mathrm{~J}$ aenuri, Ideologi Kaum Reformis, 50. Mengutip dari Clifford Geertz, The Raligion of J ava, 148-161.

${ }^{15} \mathrm{Ibid}$., 48-49. Steenbrink membedakan gerakan Islam di Indonesia menjadi salaf dan modernis. Gerakan salaf dalam perjalanan sejarahnya telah memberikan sumbangan besar terhadap modernisasi Islam. Gerakan ini melihat telah terjadi hal yang salah dalam sejarah Islam yang mengakibatkan Islam tidak cocok dengan zaman modern. Beberapa aliran di dalam gerakan ini mewujudkan "penyelesaiannya" dengan cara yang sangat dogmatis dan keras, sehingga semboyannya "kembali kepada Q ur'an dan $\mathrm{H}$ \{adith", menghasilkan skripturalisme yang sangat kaku dan tidak elastis. Di pihak lain, aliran modernis memang dipandang sangat konservatif (masih memegang tradisi lama) di bidang fiqih dan ibadah. $\mathrm{H}$ al itu diakibatkan karena pandangan mereka terhadap sejarah lampau lebih positif dan lebih toleran. Mereka tidak menganggap sejarah Islam sebagai "sejarah penyelewengan dari kebenaran Islam". Namun demikian pandangan mereka terhadap perkembangan modern juga lebih positif dan toleran. Akhirnya gerakan ini dengan cara yang lebih mudah juga bisa menerima unsur-unsur modern, tanpa perdebatan yang terlalu tajam. Baca: Steenbrink, Pesantren, 33-34. Menurut A bu Bakar Atjeh, tokoh dan organisasi penting dalam Islam di Indonesia pada permulaan abad ke-20 terbagi dalam 3 kelompok yaitu, "gerakan salaf" (gerakan dari orangorang terdahulu yang ingin kembali pada rel ulama salaf yang juga dipilih oleh Jamaluddin al-Afghani untuk menamakan gerakannya sebagai gerakan "salafiyah", gerakan ini juga dinamakan gerakan reform). Gerakan kedua adalah gerakan modernis. Sedangkan gerakan ketiga adalah gerakan Islam yang disebut gerakan politik. Baca: Lothrop Stoddard, Dunia Baru Islam, 318.

${ }^{16}$ Di antaranya Syafiq A. Mughni sebagaimana tercermin dalam karyanya mengenai pemimpim PERSIS yang diberinya judul: "Hassan Bandung Pemikir Islam Radikal." J uga Achmad J aenuri dalam studinya tentang Muhammadiyah yang diterbitkan dengan judul: "Ideologi Kaum Reformis: Melacak Pandangan Keagamaan Muhammadiyah Periode Awal" lebih cenderung menyebut PERSIS sebagai radikalis. J aenuri juga mengungkap bahwa menurut studi yang dilakukan $\mathrm{H}$ oward $\mathrm{M}$. Federspiel, fenomena radikalis ini sudah ada sejak masa $\mathrm{H}$ aji Zamzam.
} 
dipicu oleh radikalisme PERSIS. ${ }^{17}$

\section{Dinamika Sosial Fiqih Reformis-Tradionalis}

Kalau dilacak ke belakang, fenomena ketegangan reformis-tradisionalis itu dapat ditemukan jejak-jejaknya pada beberapa tahun sebelum berdirinya PERSIS (1923). Steenbrink menyebut 1910-1930 sebagai perio de waktu yang diwarnai oleh perbedaan pandangan mengenai banyak persoalan yang menghebohkan. Sebagian besar persoalan yang diperdebatkan berkaitan dengan masalah fiqih dan usllibal-fiqh, terutama apakah orang Islam wajib mengikuti mazhab atau harus bersandar langsung pada al-Q ur'an dan $\mathrm{H}$ dith. ${ }^{18}$

Pada sebagian dari periode waktu yang disebutkan Steenbrink di atas, kota Surabaya, tempat kelahiran NU, pernah menjadi kancah diskusi (debat) tentang masalah-masalah keagamaan. Sejumlah pemimpin terkemuka gerakan-gerakan Islam pernah datang ke kota ini untuk mengikuti debat tersebut. Ahmad H assan dari Singapura misalnya, sebelum bergabung dengan PERSIS, pada tahun 20-an mengunjungi Surabaya dalam kaitannya dengan usaha batik milik keluarganya. Di kota ini Ahmad Hassan melakukan diskusi tentang soal-soal khilafiyah dengan ulama Indonesia. A hmad Dahlan, pendiri dan pemimpin Muhammadiyah, juga pernah beberapa kali datang ke Surabaya dan terlibat dalam diskusi tersebut. Ahmad Dahlan pun pernah menjadi tuan rumah (menjamu) kelompok tradisionalisyang datang ke Yogyakarta untuk sebuah diskusi. ${ }^{19}$

Ahmad Surkati, salah seorang tokoh berpengaruh dalam al-Irsyad, juga pernah diundang debat oleh kalangan ulama pesantren di Masjid Ampel, Surabaya, berkaitan dengan masalah ijtihad, bid'ah, dan tawassul. Karena diperkirakan akan menimbulkan dampak negatif, debat itu akhirnya dilarang. Walaupun demikian Ahmad Surkati menganggap perlu mengklarifikasi pandangannya mengenai soal-soal yang diperdebatkan itu melalui tulisan. Ia lalu menulis buku berjudul al-M asaił al-Thalath (tiga problema) yang mengupas masalah (1) ijtihad dan taqlid, (2) sunnah dan bid'ah, dan (3) ziarah kubur dan wasilah melalui Nabi Muhammad atau para wali. ${ }^{20}$

Ali Haidar menelusuri bibit "ketegangan" di kota kelahiran NU itu semenjak kehadiran figur Pakih H asyim, seorang saudagar Minangkabau yang - di luar kegiatannya berdagangmenyempatkan diri untuk berdakwah. Dalam dakwahnya di berbagai kesempatan, Pakih Hasyim menganjurkan kaum muslimin menghapus berbagai tradisi ibadah yang mereka lakukan selama ini seperti melafalkan niat salat dengan ucapan usălli dan lain-lain. Dia juga menganjurkan kaum muslimin untuk meninggalkan kebiasaan mengambil hukum Islam dari kitab-kitab mazhab dan menggantinya dengan menggali langsung dari al-Qur'an dan $\mathrm{H}$ dith. Kegiatan dakwah Pakih H asyim seringkali diselenggarakan bekerja sama dengan al-Irsyad yang memang mempunyai pemikiran yang sejalan dengan Pakih $\mathrm{H}$ asyim. ${ }^{21}$

\footnotetext{
${ }^{17}$ Baca: J aenuri, Ideologi Kaum Reformis, 52.

${ }^{18}$ Steenbrink, Pesantren, 32.

${ }^{19}$ Baca: J aenuri, Ideologi Kaum Reformis, 53.

${ }^{20} \mathrm{Ahmad}$ Surkati (nama lengkapnya, Ahmad bin Muhł̆mmad Surkati) ulama asal Sudan yang datang ke Indonesia atas permintaan J ami'atKK hayr, tetapi kemudian bergabung dengan Al-Irsyad dan menjadi salah seorang tokoh yang berpengaruh dalam organisasi itu. Baca: Ali, NU dan Islam di Indonesia, 48.

${ }^{21}$ bid., 46.
} 
Muhammadiyah yang didirikan Ahmad Dahlan di Yogyakarta, baru memasuki Surabaya pada awal dasawarsa 20-an. Selama kira-kira delapan tahun pertama, Muhammadiyah masih membatasi wilayah operasinya di daerah Yogyakarta. Sampai suatu waktu di tahun 1917, kongres Budi Utomo digelar di Yogyakarta. A hmad Dahlan giatmembantu, termasuk menyediakan rumah tinggalnya untuk dijadikan salah satu pusat kegiatan kongres. Momen tersebut ternyata menjadi faktor penting yang membuat perhatian dari luar Yogyakarta meningkat terhadap Muhammadiyah. Permintaan untuk mendirikan cabang Muhammadiyah dari berbagai daerah di J awa berdatangan. Muhammadiyah lalu mengubah anggaran dasarnya pada tahun 1920 untuk menyediakan landasan yuridis bagi upaya perluasan kawasan operasinya ke seluruh daerah di pulau J awa. Pada tahun berikutnya, anggaran dasar diubah lagi menjadi untuk seluruh Indonesia. B eberapa kali kunjungan A hmad Dahlan ke Surabaya-di samping untuk menghadiri debat seperti disinggung di atas-adalah dalam rangka perluasan wilayah dan jaringan organisasi Muhammadiyah yang dipimpinnya itu. Di Surabaya, Ahmad Dahlan bertemu dengan, antara lain, Pakih Hasyim dan Mas Mansur. Kunjungan-kunjungannya ini kemudian membuahkan berdirinya cabang Muhammadiyah di Surabaya pada tahun 1921. Sesudah itu berdiri pula cabang Bangil, Kepanjen, dan Lamongan. ${ }^{22}$

Mas Mansur yang mendirikan cabang Muhammadiyah di Surabaya adalah patner Abdul Wahab Hasbullah yang pada tahun 1914 kembali ke tanah air setelah menempuh studinya di Mekah. Sedangkan Mas Mansur kembali ke tanah air dari menyelesaikan studinya di al-Azhar, Kairo, pada tahun 1915. Abdul Wahab sejak tahun 1914 merintis berdirinya organisasi pendidikan dan dakwah bernama Nahdæat al-Watan dan kemudian menggandeng Mas Mansur setelah kembali ke tanah air. Dengan bantuan H OS Tjokroaminoto (pemimpin SI) dan seorang

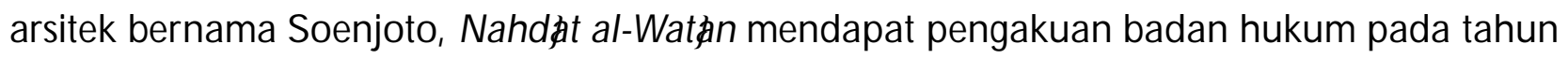
1916. Menyadari bahwa gerakan sosial pendidikan membutuhkan dana yang tidak sedikit, mereka merangkul seorang saudagar kaya dari kampung Kawatan (sebelah selatan Tugu Pahlawan, Surabaya) bernama Haji Abdul Qahar. Dipercaya sebagai direktur, H aji Abdul Qahar segera memelopori pembangunan sekolah Nahdł̆t al-Watăn yang juga berlokasi di kampungnya, Kawatan. Di sekolah itu, Mas Mansur dipercaya menjadi guru kepala, sedangkan Abdul Wahab sendiri menjadi guru biasa. Dalam waktu lima tahun pertama, cabang-cabang madrasah ini telah berdiri di Malang, Semarang, G resik, J ombang, dan beberapa tempat di Surabaya sendiri. Sebagian dari madrasah-madrasah cabang itu ada yang langsung menggunakan nama Nahd dat al-Watăn, di samping ada pula yang menggunakan nama-nama lain seperti Far' al-Watăn, Hidayat al-Watăn, Khitabat al-Watăn, Akh al-Watăn, dan lain-lain. ${ }^{23}$

Sementara Mas Mansur lebih berperan memimpin sekolah, Abdul Wahab berkonsentrasi pada penyelenggaraan kursus-kursus kepemudaan, organisasi, dan dakwah (waktu itu digunakan istilah nadwah yang berarti pertemuan pengajian untuk menyeru kebenaran), dan perjuangan. ${ }^{24}$ Usaha-usahanya ini diarahkan untuk mendidik ulama yang lebih muda tentang bagaimana merespons kritik dari kaum reformis dan untuk memfasilitasi kontak antara kedua kelompok itu

22Ibid., 41-43.

${ }^{23}$ |bid.,

${ }^{24}$ lbid., 43. 
guna mendiskusikan berbagai masalah agama dan politik. ${ }^{25}$

Mas Mansur juga ikut merintis berdirinya Taswir al-Afkar (presentasi gagasan-gagasan) pada tahun 1918 bersama K.H. Ahmad Dahlan (pemimpin sebuah pondok pesantren di kampung Kebondalem, Surabaya), Abdul Wahab, dan Mangun (anggota Budi Utomo yang mempunyai hubungan dekat dengan para ulama di Surabaya). Dalam sepuluh tahun pertama, Taswir alAfkar lebih memfungsikan diri sebagai wadah presentasi pemikiran atau gagasan. Kursus dengan pola diskusi merupakan kegiatannya yang sangat ditekankan. Dengan pola itu, para peserta (yang belajar) tidak merasa dianggap lebih rendah sebagai murid, tetapi sejajar seperti layaknya sebuah kegiatan diskusi. Memasuki sepuluh tahun berikutnya, Taswipal-Afkarmemperluas bidang kegiatannya dengan membuka sekolah biasa dan sekolah untuk yatim dan miskin. ${ }^{26}$

Mas Mansur yang cukup lama menjadi patner efektif Abdul Wahab dalam menyuburkan atmosfir dialog itu, setelah beberapa kali bertemu dengan Ahmad Dahlan (pemimpin Muhammadiyah) dan kemudian mendirikan cabang Muhammadiyah di Surabaya, resmi meninggalkan Nahdgat al-Watän pada tahun 1922. ${ }^{27}$ Mas Mansur yang alumni Mesir mulai tampak tidak sejalan pandangannya dengan A bdul Wahab yang alumni Mekah sejak di Taswir al-Afkar. Dalam memilih tema-tema diskusi yang diselenggarakan organisasi ini, Abdul Wahab cenderung untuk tidak menjadikan issu-issu khilafiyah karena potensial untuk timbulnya perpecahan. Mas Mansur tidak dapat menerima pendirian Abdul Wahab yang didukung mayoritas anggota Taswir al-Afkar tersebut. Akhirnya ia memilih surut dari kegiatan lembaga diskusi ini setelah berperan aktif di dalamnya selama lebih dari dua tahun. ${ }^{28}$

Fenomena mufaraqah (pemisahan diri) Mas Mansur dari Nahdłat al-Watąn ini dari luar tampak sebagai kejadian biasa. Tetapi di baliknya ada sesuatu yang luar biasa, yaitu benturan pandangan yang mulai menajam dan berskala luas antara kaum reformis dan kaum tradisionalis. Pokok yang menjadi kancah perbenturan pada mulanya berkisar pada persoalan ijtihad dan taqlid (bermazhab), tetapi kemudian melebar pada masalah-masalah cabang (furu'yyah) yang masih diperselisihkan (khilafiyah), semisal tahlilan untuk mendoakan orang mati, talqip mayit, doa qunut, bacaan usălli sebelum takbirat al-ihram, jumlah rakaat salat tarawih, dan lain-lain.

"Pertikaian" mengenai urusan-urusan yang tidak mendasar itu tentu saja tidak menguntungkan bagi umat Islam, bukan hanya dari segi bahwa mereka berkewajiban memelihara jalinan ukhuwah dengan saudara seiman, tetapi lebih dari itu bagi umat Islam yang sedang dijajah bangsa kafir seperti di Indonesia persatuan dan kesatuan merupakan kekayaan paling berharga yang mesti dijunjung oleh siapapun. Karena itu, ketika eskalasinya cenderung terus memanas, sejumlah eksponen Sarekat Islam (SI) pimpinan HOS Tjokroaminoto, yang memang tidak begitu tertarik memperdebatkan soal-soal kecil di bidang keagamaan, mencoba menggagas jalan keluar. Mereka mengupayakan adanya forum dialog tingkat nasional dengan melibatkan semua kelompok umat Islam dalam kerangka mencari titik temu sekaligus membahas masalahmasalah penting yang menjadi keprihatinan bersama. Sebagai organisasi yang bergerak di jalur

\footnotetext{
25] aenuri, Ideologi Kaum Reformis, 52-53.

${ }^{26} \mathrm{Ali}, \mathrm{NU}$ dan Islam di Indonesia, 43-44.

27] aenuri, Ideologi Kaum Reformis, 52-53.

${ }^{28}$ Ridwan, Paradigma Politik NU, 176.
} 
politik, SI berkepentingan dengan suasana yang kondusif bagi persatuan dan keutuhan umat Islam. Tentu SI ingin agar kekompakan internal di kalangan aktifis-aktifisnya sendiri tidak terganggu oleh pertikaian tentang masalah-masalah keagamaan itu, karena memang sebagian aktifis SI adalah tokoh-tokoh penting baik dari kubu reformis maupun tradisionalis. ${ }^{29}$

Akhirnya, dengan tajuk "Kongres Dunia Islam H india Timur" (mu'tamar al-'alam al-islami) al-hindi al-sharqiyah), selanjutnya disebut "Kongres al-Islam", forum dialog nasional itu digelar untuk pertama kalinya di Cirebon pada tanggal 31 Oktober - 2 Nopember 1922. Hadir ke kongres ini wakil-wakil dari Muhammadiyah, al-Irsyad, SI, dan eksponen "tradisional". Kelompok yang disebut terakhir ini diwakili oleh K.H. Abdul Wahab Hasbullah dan K.H. R. Asnawi dari Taswiral-Afkap. ${ }^{30}$ Sebagai pimpinan kongres, SI berusaha agar soal-soal kecil yang bukan pokok agama tidak diperdebatkan, namun yang terjadi sebaliknya. Kongres berubah menjadi ajang perdebatan seru mengenai soal-soal kecil itu. H. Agus Salim sampai menggambarkan bahwa kongres diliputi "suasana perbantahan dan pertentangan yang tajam antara guru-guru dan ulama Islam," 31 bahkan sampai "kafir-mengkafirkan dan mushrik-memushrikkan hanya karena pertikaian faham tentang perkara yang kecil-kecil sekali." ${ }^{32}$ Lebih lanjut H. A gus Salam menulis komentar-komentarnya sebagai berikut.

Malah sebagian saudara kita lebih bersaudara dengan Majusi, Yahudi dan Nasrani daripada dengan golongan Islam yang masuk perikatan al-Irsyad dan Muhammadiyah. ${ }^{33}$ Ada pula yang datang mementingkan agama Islam. Kedatangan mereka semata-mata untuk mengalahkan, akan menghancurkan haluan Islam yang lain-lain daripada yang sudah menjadi pusaka turun-temurun di dalam bangsa dan tanah air kita, malah umumnya seluruh dunia. Pendek kata kedatangan mereka jauh dari mencari persatuan dan persaudaraan umat Islam. Malah mereka tidak menghendaki perdamaian. ${ }^{34}$ Tak lain tak bukan hanyalah kepentingan beberapa fihak yang sekedar merebut kemenangan faham atas beberapa cabang yang sekali-kali tidak menjadi pokok agama. ${ }^{35}$

Kongres kedua, tidak ditemukan catatan mengenai inwal penyelenggaraannya. Sedangkan kongres ketiga digelar pada bulan Desember tahun 1924. Sebelumnya tersiar berita bahwa khalifah 'Abd al-Majid telah diturunkan dari jabatannya oleh Mustgafa Kamal (pemimpin nasionalis Turki). Turki tidak mau menanggung sendiri beban khilafah dan karena itu ia membubarkannya

\footnotetext{
${ }^{29}$ Di antara aktifis SI dari kalangan reformis adalah K.H Ahmad Dahlan, K.H. Mas Mansur, dan K.H Fachruddin. Sedangkan aktifis SI dari kalangan tradisionalis adalah K.H. Abdul Wahab Hasbullah, K.H. R. Asnawi, dan K.H. M. Dahlan (Kertosono). Baca: Ibid., 180.

30lbid., 182.

${ }^{31} \mathrm{Ali}$, NU dan Islam di Indonesia, 47. Mengutip dari Hindia Baroe, 27 Mei 1924.

${ }^{32} \mathrm{lbid}$., Mengutip H. Agus Salim, "Persatuan Pemimpin Islam", dalam Hindia B aroe, 19 Februari 1926. Menurut Steenbrink, perkara kecil-kecil yang dipertikaian berkaitan dengan akidah, ibadah, dan praktik hidup sehari-hari, seperti tentang gelar kehormatan dan hak-hak utama yang diberikan kepada keturunan $\mathrm{N}$ abi Muhammad yang oleh karena itu memakai title sayyid, boleh tidaknya seseorang menjadi anggota tarekat dan khususnya memberikan pisisi sosial istimewa terhadap pemimpin tarekat, berpahala tidaknya pembacaan al-Qur'an dan wirid untuk orang yang meninggal dunia, keharusan duduk atau berdiri pada peringatan Maulid, dan apakah Nabi Muhammad hadir pada salah satu pembacaan wirid atau tidak. Baca: Steenbrink, Pesantren, 31.

${ }^{33} \mathrm{Ali}, \mathrm{NU}$ dan Islam di Indonesia, h. 47. Mengutip H. Agus Salim, "Persatuan Pemimpin Islam", dalam Hindia Baroe, 19 Februari 1926.

34lbid. Mengutip H. Agus Salim, "Persatuan Pemimpin Islam”, dalam Hindia Baroe, 19 Februari 1926.

${ }^{35}$ bid. Mengutip H. Agus Salim, "Persatuan Pemimpin Islam", dalam H india Baroe, 20 Februari 1926.
} 
dengan mengusir Khalifah 'Abd al-Majid keluar dari Turki. Urusan khilafah diserahkan Turki kepada umat Islam sedunia. Setelah itu tersiar pula kabar bahwa untuk merespons perkembangan di Turki itu ulama Mesir, di bawah pimpinan Shaykh al-Azhar, akan menyelenggarakan pertemuan internasional untuk membahas soal khilafah itu. Pada level domestik Mesir, mereka sendiri pada tanggal 24 Maret 1924 telah memutuskan pentingnya keberadaan lembaga khilafah itu bagi umat Islam. ${ }^{36}$

Perkembangan politik Islam di Turki dan rencana Mesir untuk menyelenggarakan pertemuan internasional guna merespons perkembangan tersebutcukup kuat mengundang minat elite muslim Indonesia untuk ikut aktif mengambil bagian. Sebuah pertemuan yang diselenggarakan di Surabaya pada 4 Agustus 1924, yang dihadiri SI, Muhammadiyah, al-Irsyad, Atta'dibiyah, Taswir al-Afkar, Ta'mir al-Masajid, dan sejumlah perhimpunan lain, memutuskan membentuk Komite Khilafah dan menyelenggarakan persidangan luar biasa Kongres Al-Islam untuk mengirim delegasi ke Kairo. ${ }^{37}$

Komite Khilafah itu diketuai oleh Wondoamiseno dari SI, wakil ketua K.H . Abdul Wahab, sekretaris A.M. Sangaji, wakil sekretaris R. Simoen Bd., dan bendahara Syekh Muhammad Alamudi. Sedangkan anggota-anggotanya terdiri dari Sa'id Idrus Almasyhur, Mas Mansur, H asan Gipo, Mansur J amani, U mar Hubesy, dan lain-lain. ${ }^{38}$ Personil delegasi yang ditetapkan untuk menghadiri pertemuan internasional di Kairo adalah Soerjopranoto (SI), Fakhruddin (Muhammadiyah), dan Abdul Wahab (Taswir al-Afkar). ${ }^{39}$

Kongres al-Islam ketiga yang digelar di Surabaya atas prakarsa Komite Khilafah pada 2426 Desember 1924 menyepakati sejumlah agenda, di antaranya membahas persoalan-persoalan keagamaan yang diperselisihkan dan rencana pengiriman delegasi ke Kairo. Mengenai persoalanpersoalan keagamaan yang diperselisihkan, masalah ijtihad, kedudukan kitab tafsir al-Manap, kedudukan ajaran Muhammadiyah dan al-Irsyad diangkat sebagai issu-issu yang dibahas. ${ }^{40}$ Perdebatan seru antara sayap reformis dan tradisionalis kemudian mengantarkan kongres pada kesimpulan yang dipandang mencerminkan dicapainya jalan kompromi, sehingga surat kabar $\mathrm{H}$ india Baroe yang dipimpin $\mathrm{H}$. Agus Salim mengomentari hasil keputusan tersebut dengan anak judul "M oesjawarah O elama, B oeah jang Lezat". Berikut ini butir-butir keputusan kongres tersebut.

1. ljtihad dapat dilakukan dengan syarat-syarat tertentu antara lain mengetahui nas\$, $\$$ al-Qur'an dan hæ्वdith; mengetahui ijma'yulama; mengerti bahasa Arab dengan baik; mengetahui tentang 'am, khasy mufas\$\$\$l, mujmal dalam al-Q ur'an; naskh, mansukh, mutlaq, muqayyad, mujmal

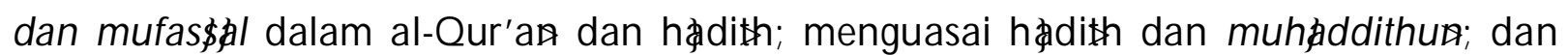
mengetahui asbab al-nuzul: "Barangsiapa yang bersifat dengan sjarat-sjarat terseboet di atas, maka wadjiblah atasnja beridjtihad dan berdosalah djikalaoe tidak beridjtihad", ditegaskan dalam keputusan tersebut.

\footnotetext{
${ }^{36}$ lbid., 55-56.

${ }^{37}$ Ibid., 55.

${ }^{38}$ |bid., h. 118. Mengutip dari Bendera Islam, 30 Oktober 1924.

${ }^{39}$ Ridwan, Paradigma Politik NU, 183-184.

${ }^{40}$ Pembahasan ajaran kedua organisasi ini adalah dalam kaitannya dengan aliran Wahabi. Pada saat itu gelar Wahabi diberikan kepada semua kaum modernis (reformis) yang tidak lagi mau terikat kepada mazhab tertentu. Baca: catatan kaki nomor 123 dalam Steenbrink, Pesantren, 67.
} 
2. Salaf ialah ulama fukaha, muhdddithun dan ahli tauhid abad pertama sampai dengan abad ketiga Hijriah, selain itu tidak termasuk kategori salaf. Kitab tafsir al-Qur'an diterima bila ditulis oleh orang yang mu'tamad (representatif) didasarkan atas penafsiran yang sah.

3. Mengakui bahwa Muhammadiyah dan al-Irsyad tidak termasuk Wahabi, tidak keluar dari mazhab empat, dan tidak mengafirkan orang yang melakukan tawassul. Tentang tawassul masih akan dilanjutkan pembicaraannya di lain kesempatan. Tidak mengingkari adanya karamah, anugerah keistimewaan dari Tuhan kepada seorang hambaNya yang mukmin dan beramal saleh, dan menghormati kitab-kitab ulama yang mu'tamad dan diakui. ${ }^{41}$

Ketika kongres memasuki bahasan tentang delegasi ke Kairo, pembicaraan sempat menyinggung kabar yang baru tersiar bahwa SharifH «siyn juga berencana menggelar pertemuan serupa di Hijaz. Hasan Ali, salah seorang peserta kongres, tidak setuju Indonesia mengirim delegasi ke Kairo maupun ke Hijaz. Sebagian peserta lainnya tidak setuju membentuk komite karena khawatir di Kairo tidak mendapat sambutan. Mereka mengusulkan komite itu dibentuk pasca pertemuan Kairo saja. Sebagian lagi tidak setuju karena pengiriman delegasi itu biayanya cukup besar. Lebih baik biaya itu digunakan untuk membangun madrasah atau lainnya. Ahmad Ghana'im, guru sekolah berasal dari Mesir, bisa meyakinkan peserta kongres bahwa delegasi akan disambut baik di Kairo. Kongres akhirnya menyetujui pengiriman delegasi ke Kairo. Sedangkan rencana Hijaz kurang mendapat tanggapan, karena persiapan SyarißH «siyn dianggap kurang matang. ${ }^{42}$

Belum sempat pertemuan $\mathrm{H}$ ijaz digelar, SharißH wsayn keburu harus menghadapi serbuan pasukan 'Abd al-'Aziz bin Sa'ud yang kemudian berhasil merebut kekuasaan dari genggamannya. Dengan kekalahan SharißH \&sayn, rencana pertemuan Hijaz dengan sendirinya batal digelar. Di Mesir, meletusnya perang perebutan kekuasaan di $\mathrm{H}$ ijaz menjadi salah satu pertimbangan untuk menunda pertemuan Kairo. Menurut mereka, kehadiran wakil $\mathrm{H}$ ijaz memiliki arti yang sangat penting. Dalam keadaan negeri Hijaz dilanda krisis politik yang serius sangat kecil peluang kehadiran wakilnya pada pertemuan Kairo. Alasan lain, Mesir sendiri perlu lebih dahulu mengirim utusan ke seluruh dunia Islam untuk menjelaskan rencana pertemuan Kairo itu serta hal lain menyangkut perkembangan dalam negeri Mesir yang sedang menyelenggarakan pemilu. Sementara pertemuan Kairo ditunda satu tahun, penguasa baru Hijaz mengumumkan rencananya untuk menyelenggarakan pertemuan internasional guna membahas pengaturan Mekah dan Madinah. ${ }^{43}$

Steenbrink menyebut peperangan di semenanjung Arab itu sebagai "peperangan Wahabi". ${ }^{44}$ Memang 'Abd al-'Aziz bin Sa'ud (1880-1953), yang menyerbu Hijaz kemudian menggulingkan SharißH \&sayn, beraliran Wahabi dan merupakan orang pertama dari keturunan keluarga Sa'ud yang berhasil membangun kembali kerajaan dan dinasti Wahabi di J azirah Arab dengan sebutan Kerajaan Arab Sa'udi (al-Mamlakah al-'Arabiłah al-Sa'udiyłah). ${ }^{45}$ Karena itu

\footnotetext{
${ }^{41} \mathrm{Ali}$, NU dan Islam di Indonesia, h. 52. Mengutip dari Hindia Baroe, 7 J anuari 1925.

${ }^{42}$ Ibid., 118. Mengutip dari Bendera Islam, 30 O ktober 1924

43lbid., 56-57. Berita penundaan pertemuan Kairo dikutip dari Hindia B aroe, $30 \mathrm{~J}$ anuari 1925.

${ }^{44}$ Steenbrink, Pesantren, 67.

${ }^{45}$ Dewan Redaksi, “'Abdul Aziz Ibnu Sa'ud”, Ensiklopedi Islam, Vol. 1, 11.
} 
kemenangan Ibn Sa'ud membuat issu tentang Wahabi menguat kembali setelah sempat melemah oleh hasil keputusan kongres Surabaya yang memosisikan Muhammadiyah dan al-Irsyad sebagai bukan Wahabi, termasuk pula oleh issu politik internasional tentang pembubaran khilafah di Turki. Reputasi Wahabi yang dikenal radikal, dogmatis, dan tidak mengenal kompromi, membuat kalangan tradisionalis mengkhawatirkan kemenangan 'Abd al-'Aziz bin Sa'ud akan segera diikuti dengan penghapusan (pembasmian) tradisi keagamaan menurut ajaran mazhab dari tanah $\mathrm{Hijaz.}$ Padahal wilayah itu, di samping menjadi tujuan perjalanan 'ubudiyah (haji) umat muslimin sedunia, juga menjadi salah satu tujuan perjalanan ilmiah yang penting. ${ }^{46}$

Kekhawatiran sayap tradisionalis ini disuarakan Abdul Wahab dalam sidang-sidang Komite Khilafah. Tetapi, berbeda dengan tradisionalis, sayap reformis menganggap tidak ada yang perlu dikhawatirkan dari peralihan kekuasaan di $\mathrm{Hijaz}$ tersebut karena tujuan Ibn Sa'ud menyerbu $\mathrm{H}$ ijaz adalah untuk memperbaiki tatalaksana ibadah haji yang di waktu sebelumnya kacau, banyak terjadi perampokan, dan banyak suku Arab yang melarikan diri. ${ }^{47}$

Terjadinya polarisasi pemaknaan terhadap perkembangan politik terbaru di $\mathrm{H}$ ijaz tersebut, bagaimanapun, membawa pengaruh pada proses lebih lanjut menyangkut penunjukan delegasi ke pertemuan internasional yang akan digelar di sana. Misalnya dalam Kongres al-Islam ke-4 yang antara lain membahas penunjukan delegasi tersebut, representasi kaum tradisionalis tidak tercermin di dalamnya. Kongres yang diselenggarakan di Yogyakarta pada Agustus 1925 dan hanya diikuti oleh 43 utusan SI, 10 Muhammadiyah, dan selebihnya perhimpunan lokal itu memutuskan delegasi Hijaz terdiri dari H. Abdullah Siraj (Penghulu Pakualaman) dan Soegeng yang dipilih karena pertimbangan kemampuannya berbahasa Inggris. ${ }^{48}$

Kongres Yogyakarta membuat kelompok tradisionalis merasa aspirasi mereka tentang $\mathrm{Hijaz}$, yang sering disuarakan Abdul Wahab dalam sidang-sidang Komite Khilafah, terancam masuk keranjang sampah. Situasi ini mendorong Abdul Wahab berpikir untuk memberangkatkan aspirasi kalangan tradisionalis dengan menggunakan kendaraan sendiri. Sebelum berakhirnya tahun 1926, ide itu sudah direalisasikannya dengan membentuk Komite Hijaz. ${ }^{49}$

Komite Hijaz yang dibentuk sebelum J anuari 1926 itu diketuai Hasan Gipo, wakil ketua Saleh Syamil, sekretaris Muhammad Shadiq Setiyo, dan wakil sekretaris Abdul Halim. K.H . Abdul Wahab sendiri menjadi penasehat bersama K.H. Masyhuri dan K.H. Khalil. Komite Hijaz melakukan pertemuan di rumah K.H. Abdul Wahab H asbullah di kampung Kertopaten Surabaya pada 31 J anuari 1926 (16 Rajab 1344). Dua keputusan penting dihasilkan dalam pertemuan itu. Pertama, mengirim delegasi ke Mekah untuk bertemu langsung dengan raja 'Abd al-'Aziz bin Sa'ud guna menyampaikan aspirasi agar ajaran agama yang telah menjadi tradisi dan ajaran

\footnotetext{
${ }^{46}$ Kaum tradisionalis mengkhawatirkan ajaran mazhab Shafi'itidak boleh lagi diajarkan di Mekah, padahal Mekah untuk kelompok tradisional pada waktu itu tetap merupakan perguruan yang paling disukai. Baca: cacatan kaki nomor 123 dalam Steenbrink, Pesantren, 68.

${ }^{47} \mathrm{Ali}$, NU dan Islam di Indonesia,. 56-57. Mengutip Hindia Baroe, $30 \mathrm{~J}$ anuari 1925.

${ }^{48}$ Ibid., 119-120. Mengutip Hindia Baroe, 8 Pebruari 1926.

${ }^{49}$ Menurut Aboebakar A tjeh, lembaga yang dibentuk itu bernama "Komite Merembuk Hijaz". Tiga tahun kemudian A bdul Wahab Hasbullah bersama kawan-kawannya dari NU berangkat ke Mekah untuk membicarakan persoalan yang berhubungan dengan ibadah dan pengajaran agama menurut mazhab Shafi' $i>P a d a$ saat itu, Raja Ibnu Saud menjanjikan tidak akan bertindak terlalu keras dan memahami keinginan NU tersebut. Baca: A boebakar Atjeh, Sedjarah Hidup K.H. A. Wahid Hasyim, 471-473. Dikutip dalam Steenbrink, Pesantren, 68.
} 
mazhab tetap dihormati. Kedua, - setelah timbul masalah atas nama organisasi apa delegasi itu dikirim - membentuk organisasi sebagai wadah persatuan para ulama dalam tugas memimpin umat menuju tercapainya 'izz al-Islam wa al-muslimin. Atas usul K.H. Mas 'Alwi 'Abdul 'Aziz (Malang) organisasi itu diberi nama Nahdlatul Ulama (NU). Dengan berdirinya NU, Komite Hijaz dibubarkan. ${ }^{50}$

Tidak berselang lama setelah NU lahir, kongres al-Islam ke-5 digelar di Bandung pada Februari 1926, Sebelum kongres, kalangan reformis melakukan pertemuan lobi di Cianjur untuk merancang perubahan keputusan kongres Yogyakarta mengenai delegasi $\mathrm{H}$ ijaz. Kongres Bandung dihadiri 235 utusan, 138 di antaranya perkumpulan Islam di Yogyakarta yang memberi mandat kepada $\mathrm{H}$. Fachruddin (Muhammadiyah) sebagai juru bicara. Abdul Wahab tidak bisa mengikuti seluruh acara kongres karena di tengah acara tersebut datang telegram bahwa ayahandanya sakit keras. Akhirnya kongres memutuskan mengganti personil delegasi Hijaz dengan Tjokroaminoto (SI) dan Mas Mansur (Muhammadiyah). ${ }^{51}$

Abdul Wahab sendiri kemudian mundur dari jabatannya sebagai wakil ketua Komite Khilafah. Pengunduran diri Abdul Wahab itu, menurut Steenbrink, disebabkan dia tidak jadi dikirim sebagai utusan karena alasan pengetahuan bahasa yang kurang di samping pengalaman dunia yang tidak cukup luas. Sedangkan menurut kelompok lainnya, dia tidak dikirim karena akan membela kemerdekaan mazhab Shafi'i>di kota Mekah yang telah dikuasai Wahabi. Nyatanya, memang, orang-orang yang dikirim ke Mekah hanyalah mereka yang menolak taqlie dan dicap Wahabi, termasuk Mas Mansur. ${ }^{52}$ Sementara itu, tiga tahun kemudian Abdul Wahab bersama kawan-kawannya berangkat ke Mekah sebagai delegasi NU untuk membicarakan persoalan yang berhubungan dengan ibadah dan pengajaran agama menurut mazhab Shafi'i> Pada saat itu, Raja Ibnu Sa'ud menjanjikan tidak akan bertindak terlalu keras dan memahami keinginan NU tersebut. ${ }^{53}$

\footnotetext{
${ }^{50} \mathrm{Ali}, \mathrm{NU}$ dan Islam di Indonesia, 59.; Baca juga: Dewan Redaksi, “Nahdatul Ulama”, Ensiklopedi Islam, Vol. 3, 353.

${ }^{51} \mathrm{Ali}$, NU dan Islam di Indonesia, 119-120. Mengutip Hindia Baroe, 8 Pebruari 1926.

52Steenbrink, Pesantren, 67.

${ }^{5}$ Ibid., 68. Mengutip Aboebakar Atjeh, Sedjarah Hidup K.H. A. Wahid Hasyim, 471-473. Delegasi NU membawa surat resmi tertanggal 5 Syawal $1346 \mathrm{H}$. kepada raja $\mathrm{H}$ ijaz dan N ejed. Di dalam surat itu NU menuntut, pertama, kebebasan bermazhab di negeri Hijaz dengan salah satu mazhab yang empat yang dilakukan dengan penggiliran antara imam-imam dalam salat, terutama salat J um'at di Masjidil Haram.Kedua, memakmurkan tempat-tempat bersejarah yang terkenal karena di sana berdiri masjid-masjid. Ketiga, mengumumkan ke seluruh dunia Islam rincian biaya-biaya yang diperlukan oleh orang-orang haji sehingga tidak ada pungutan-pungutan lain di luaryang ditentukan oleh pemerintah secara resmi. Keempat, menuangkan hukum dan aturan yang berlaku di negeri Hijaz dalam bentuk tertulis agar jangan sampai terjadi pelanggaran. Kelima, mohon balasan surat bahwa kedua utusan yang dikirim telah menyampaikan surat mandat mereka dan menyampaikan permohonan dan tuntutan tersebut. Surat NU ini kemudian dibalas oleh Raja Hijaz dengan surat nomor 2082, tanggal 24 Zulhijjah $1346 \mathrm{H}$. Isi surat menegaskan bahwa, pertama, dua utusan NU, yakni Abdul Wahab Hasbullah dan Ahmad G hanaim al-Amir sudah menghadap dan melaksanakan mandat mereka. Kedua, tidaklah tertegah segala amal perbuatan yang menyenangkan orangorang yang naik haji dan tidak terlarang kaum muslimin yang berkeinginan melakukan segala amal perbuatan yang baik sesuai dengan syariat hukum Islam. Ketiga, bahwa kaum muslimin adalah bebas merdeka dalam segala urusan mereka kecuali tidak ada dalil yang menghalalkannya pada al-Q ur'an, al-Sunnah, mazhab-mazhab Salaf al-S \{alih dan tidak ada pada fatwa para imam mazhab empat. Apa yang sesuai dengan semua itu kami pun mengamalkannya. Lihat kutipan surat-surat ini dalam Anggaran Dasar dan Anggaran Rumah Tangga Nahdlatul Ulama (J akarta: Sekretariat J enderal Pengurus Besar Nahdlatul Ulama, t.t.), 95-99.
} 
Peristiwa-peristiwa di atas dalam keseluruhannya merefleksikan eskalasi ketegangan yang terus meningkat antara kaum tradisionalis dan kaum reformis menyangkut issu-issu keagamaan, utamanya fiqih dan usjlbal-fiqh. Dalam pergulatan ketegangan yang terlembagakan dalam kongres-kongres al-Islam sejak tahun 1922, sidang-sidang Komite Khilafah, sampai lahirnya NU yang mengakomodasi aspirasi kaum tradisonalis, kehadiran PERSIS dapat dikatakan relatif tidak tampak. Ketika ajaran Muhammadiyah dan al-Irsyad dibedah dalam Kongres al-Islam ke-3 yang digelar di Surabaya pada Desember 1924, ajaran PERSIS malah tidak disinggung-singgung. Padahal, bila dihitung dari kelahirannya, ketika itu PERSIS sudah berumur satu tahun tiga bulan. Di samping itu, dalam kesadaran orang-orang nahdiyyin, paham keagamaan kaum reformis yang dianggap berada di posisi terdepan dalam berseberangan dengan faham keagamaan NU bukanlah PERSIS, melainkan Muhammadiyah. Karena itu, terasa ada kesulitan untuk menerima tesis J aenuri bahwa penyebab munculnya NU yang secara ideologis sangat ekstrim membela pandangan keagamaan kelompok tradisionalis adalah radikalisme PERSIS.

Dengan berdirinya NU, aspirasi atau pandangan keagamaan kaum tradisional, khususnya di bidang fiqih, menjadi terakomodasi. Lembaga-lembaga pendidikan pesantren yang merupakan basis keilmuan fiqih tradisional seperti memperoleh payung untuk "bersinergi" dalam forum bahth al-masaił NU, baik untuk merespons persoalan-persoalan keagamaan aktual maupun menjawab serangan kaum reformis. Terkait dengan yang disebut terakhir, "cara penetapan hukum Islam" langsung masuk agenda bahasan bahth al-masaił perdana yang digelar NU pada muktamarnya yang ke-1 pada tahun 1926 di Surabaya, karena masalah tersebut paling banyak disorot dan dikritik kaum reformis.

\section{Penutup}

Pergulatan fiqih tradisionalis versus fiqih reformis ini terus berlangsung sedemikian rupa sampai sekarang dan menjadi bagian dari realitas yang eksis di dunia sosial obyektif umat Islam Indonesia. ${ }^{54}$ Pergulatan kedua corak fiqih tersebut berlangsung dalam moda dialektik yang dinamis. Dalam moda seperti itu, munculnya ide reformasi keagamaan adalah suatu keniscayaan sejarah, yaitu ketika sesuatu doktrin agama sudah bergulat panjang dengan realitas sosial. Ideide reformasi yang mengejawantah dalam bentuk rekonstruksi doktrinal pada dasarnya akan selalu diwarnai oleh ketegangan-ketegangan dan/atau bahkan disharmoni sosial yang intensitasnya selaras dengan kekakuan dan radikalitas yang menghiasi rekonstruksi doktrinal itu sendiri. Menurut kelazimannya, pandangan yang negatif terhadap historisitas Islam, dalam arti ada hal yang salah di sana sehingga Islam tidak sesuai dengan zaman modern, cenderung bermuara pada corak penyelesaian yang dogmatis dan skriptural. Sebaliknya, pandangan yang

\footnotetext{
${ }^{54}$ Panjangnya masa pergulatan itu ditandai, antara lain, oleh munculnya sejumlah karangan yang mencerminkan suasana itu. Banyak fatwa A. H assan yang dikumpulkan dalam bukunya Soal J awab tentang Berbagai Masalah Agama berasal dari perdebatan antara tahun 1910-1930, yang kemudian dihidupkan lagi. Kumpulan Fatwa Siradjuddin Abbas, 40 Masalah Agama, serta Muhammad Arsjad Thalib Lubis, Fatwa, yang diterbitkan pada tahun 1970 dan 1971 membuktikan bahwa perdebatan ini berlangsung lama. Pada tahun 1971 seorang mahasiswa pada IAIN, cabang Malang lulus dengan skripsi yang berjudul: Tahlil sebagai Media Dakwah Islamijah (lihat Pandji Masyarakat 6-1972), 99, di mana diberikan catatan, bahwa diskusi diharapkan tidak akan dihidupkan lagi. Baca: Catatan kaki nomor 55 dalam Steenbrink, Pesantren, 29.
} 
lebih positif dan lebih toleran, cenderung memunculkan konservativisme yang mengejawantah kental dalam bentuk-bentuk pandangan, sikap, dan prilaku yang mencerminkan karsa kuat untuk memegangi tradisi.

Dalam perjalanan waktu yang panjang, pergulatan dialektik antara fiqih tradisonalis versus fiqih reformis yang telah melahirkan ketegangan dan disharmoni yang berpasang-surut itu selalu menyediakan ruang kepada kedua belah pihak untuk saling bertukar, saling mempersepsi kebiasaan pihak lainnya, dan kemudian dalam batas-batas tertentu saling mengadopsi. Dalam proses dialektik seperti itu bisa saja terjadi perubahan-perubahan pandangan keagamaan yang bergerak maju-mundur di antara kutub reform dan kutub tradisi.

Kelompok tradisionalis yang direpresentasikan oleh Taswipal-Afkapdalam Kongres al-Islam tahun 1924 turut merumuskan keputusan bahwa ijtihad dapat dilakukan dengan syarat-syarat tertentu. Ketika pada tahun 1926 mendirikan NU, pandangan mereka bergeser mengental ke kutub tradisional, yakni dengan mewajibkan umat Islam menerima pendapat Mazhab Empat. Pada tahun 1935, kekentalan itu sedikit berkurang, seperti tercermin dalam keputusan bahth almasaił pada muktamar NU ke-11 di Banjarmasin yang melarang ijtihad langsung dari al-Qur'an dan $\mathrm{H}$ dith tanpa mempelajari lebih dahulu kitab-kitab fiqih yang ada. Artinya, untuk mereka yang sudah mempelajari kitab-kitab fiqih, boleh berijtihad. Pada tahun 1992, melalui keputusan bahth al-masaił dalam Munas NU di Bandar Lampung, kaum tradisionalis siap melaksanakan ijtihad itu secara jama'łłkolektif) oleh para ahlinya, yaitu ketika pemecahan hukum tidak lagi bisa diatasi dengan kitab-kitab fiqih yang ada.

Pada ranah individual, proses dialektik itu juga memberi peluang bagi munculnya fenomena "blasteran reformis-tradisionalis". Dalam konteks spesifik Muhammadiyah dan NU, untuk menyebut fenomena tersebut lazim dipakai istilah "Muhammadinu" atau "Muhammad NU", yakni orang tradisionalis yang tidak seberapa kental (NU bernuansa Muhammadiyah), atau orang reformis yang tidak begitu kenceng (Muhammadiyah bernuansa NU). Di kalangan mereka ini ketegangan atau disharmoni sosial relatif tidak terekspresi ke permukaan. Di samping karena dalam beberapa hal bisa saling mengadopsi pendapat, mereka memang lebih mempunyai kecenderungan untuk saling bertoleransi, saling menghargai, dan saling memahami posisi masingmasing.

\section{Daftar Rujukan:}

Anggaran Dasar dan Anggaran Rumah Tangga Nahdlatul Ulama (J akarta: Sekretariat) enderal Pengurus Besar Nahdlatul Ulama, t.t.).

Atjeh, Aboebakar, Sedjarah Hidup K.H. A. Wahid Hasyim.

Benda, H ary J ., Bulan Sabit dan M atahari Terbit, penerjemah: Daniel Dakhidae (J akarta: Dunia Pustaka J aya, 1980).

Boland, B.J ., The Struggle of Islam in Modern Indonesia (The Hague: Martinus Nijhoff, 1982).

Dewan Redaksi Ensiklopedi Islam, Ensiklopedi Islam, vol. 2, 3, dan 4, (J akarta: PT Ichtiar B aru Van Hoeve, 1993).

Haidar, M. Ali, NU dan Islam di Indonesia: Pendekatan Fikih dalam Politik (J akarta: PT G ramedia 
Pustaka Utama, 1994).

Hamid, Mas'an, Tradisi Pembacaan Simt\} al-Durar dalam Masyarakat Keturunan Arab di Kawasan Ampel Surabaya: Kajian Tentang Bentuk, Isi, dan Fungsi Sastra (Disertasi Doktor pada IAIN Sunan Ampel, Surabaya, 2008.

J aenuri, Achmad, Ideologi Kaum Reformis: Melacak Pandangan Keagamaan Muhammadiyah Periode Awal (Surabaya: LPAM, 2002).

Karim, A. G affar, Metamorfosis NU dan Politisasi Islam Indonesia (Yogyakarta: LKiS, 1995).

Nasution, H arun, Pembaharuan dalam Islam: Sejarah Pemikiran dan G erakan (J akarta: Bulan Bintang, 1975).

Ridwan, Paradigma Politik NU: Relasi Sunni-NU dalam Pemikiran Politik (Purwokerto: STAIN Purwokerto Press, 2004).

Steenbrink, Karel A., Pesantren, Madrasah, Sekolah: Pendidikan Islan dalam Kurun Modern, cetakan 2 (J akarta: LP3ES, 1994).

Stoddard, Lothrop, Dunia Baru Islam (J akarta, 1966). 